\title{
黄河中流支川における土砂輸送と抵抗則に関する研究 SEDIMENT TRANSPORT AND FLOW RESISTANCE IN TRIBUTARIES OF THE MIDDLE YELLOW RIVER
}

\author{
橋本晴行 $^{1} \cdot$ 高岡広樹 $^{2} \cdot$ 池松伸也 $^{3}$ \\ Haruyuki HASHIMOTO, Hiroki TAKAOKA and Shinya IKEMATSU \\ 1 正会員 工博 九州大学助教授 大学院工学研究院（干812-8581 福岡市東区箱崎 6-10-1） \\ 2 正会員 博士（工学）八千代エンジニヤリング株（テ810-0062＼cjkstart福岡市中央区荒戸 2-1-5） \\ 3 正会員 九州大学技術員 大学院工学府（干812-8581 福岡市東区箱崎 6-10-1）
}

\begin{abstract}
The Yellow River basin has serious problems of flood and irrigation due to hyper-concentrated flood from the tributaries of the middle river reach. In order to solve these problems, it is important to estimate sediment transport and flow resistance in the tributaries.

The purpose of the present study is to investigate sediment transport and flow resistance of hyper-concentrated flood flows in the tributaries of the middle Yellow River. The Kuye, Tuwei and Jialu River basins are selected as study areas. First, sediment transport and flow resistance characteristics are examined using the field and laboratory data of flow and sediment discharge. Second, the theories based on the Newtonian and non-Newtonian fluid model are compared with the field and laboratory data. As a result, it is found that the non-Newtonian fluid model is appropriate for the Kuye River and the Newtonian fluid model is valid for the Tuwei and Jialu River.
\end{abstract}

Key Words: Yellow River, hyper-concentrated flow, mud flow, sediment transport, flow resistance

\section{1. はじめに}

黄河中流域では，その支川が黄土高原を深く切り刻み ながら通過するため，微細土砂を高濃度に含有した洪水 が本川に流れ込み, ピーク時で体積濃度 C=15\% - 40\%に も達するとともに，時にはそれ以上の高濃度流れが発生 している，このような高濃度洪水は，流域内の水利・電 源開発などの障害や河床上昇による洪水疎通能力の低下 などを引き起こしている，そのため，高濃度洪水による 土砂流出の評価が長年の課題となっている. 土砂流出の 正確な予測を行うためには，河道における高濃度洪水の 普遍的な抵抗と流砂量則の解明が必要である.

黄河における，微細土砂の高濃度流れの特性について は芦田らの研究 ${ }^{1)}$, 2)がある. また, 黄河における土砂輸 送モデルの構築の一環として, 循環水路を用いた高濃度 流れの実験や現地河道調査が著者らによって実施されて きた ${ }^{3)}$. 一方，中国においては，高濃度流れに対してビ ンガム流体モデルを用いた研究が数多く行われてきた ${ }^{4)}$ しかしながら，普遍的な抵抗則や流砂量の評価式が明ら かになるまでには至っていない.

本研究の目的は，黄河中流支川において現地観測の水 理・水文資料 ${ }^{5)}$ の解析を通じて, 高濃度洪水の抵抗則と 土砂輸送の特性を解明するとともに，その成果をもとに 流出土砂量の評価法について検討することである. 調査 対象河川は黄河中流支川の窟野河 (Kuye River), 秃尾河 (Tuwei River) および佳芦河 (Jialu River) である(図-1)。まず，観測点において測定された水

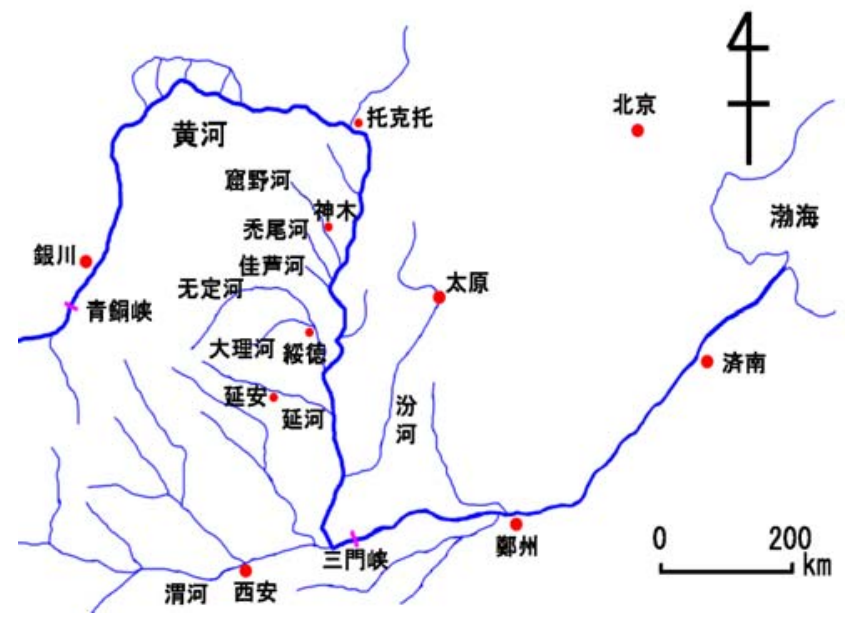

図-1 黄河中流域における主な支川

理・水文量の資料解析を行い，流域の流出係数，流出土 砂の特性, 流砂濃度, 抵抗則について調べる. 次いで, 実験室とは異なる流量規模における流れの抵抗則と流砂 量の評価法について検討する.

最後に，貯留関数法を用いて水理・水文観測点におけ る流出解析を行い，流量ハイドログラフを求める.さら に，求めた流量に対して流砂量式を用いることにより流 砂量ハイドログラフを得て，観測值と比較する.

\section{2. 対象河川の流域特性}

図-2は, 解析対象河川の窟野河流域の平面図 


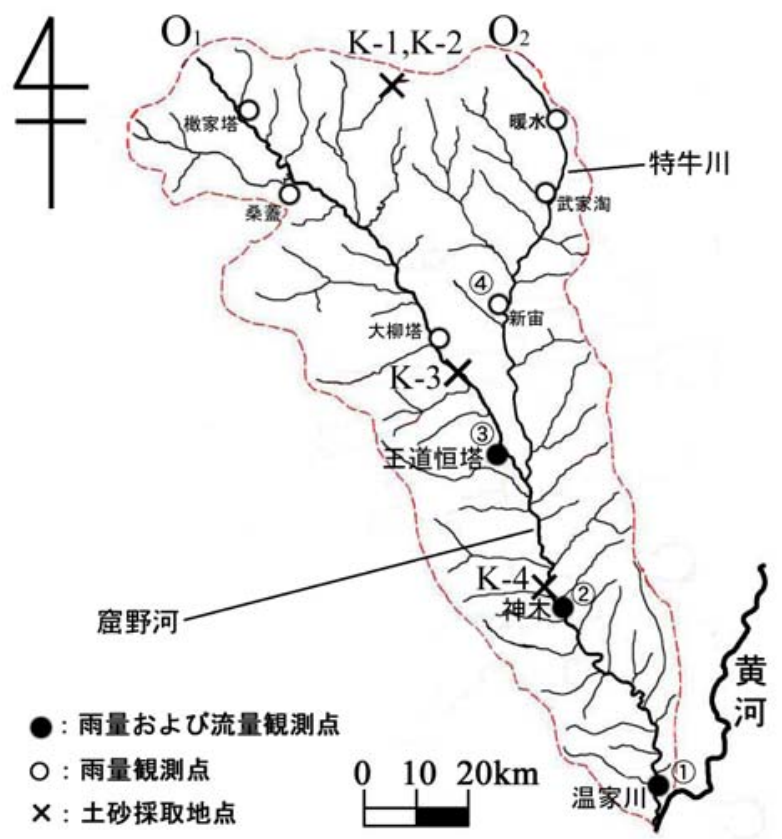

図-2 窟野河流域の平面図

を示す.ここに図中の丸印は水理・水文観測点の 位置を表している。表-1 は調査対象河川流域の特性 を示す。流域面積から見ると, 我が国では，窟 野河は淀川, 秃尾河は吉野川, 佳芦河は太田川 にそれぞれ匹敵する。

窟野河流域は地形的には3つの領域に分けられる.

下流域は黄土丘陵，中流域は砂質丘陵，また，上流域の 一部は磁質丘陵である. 河床勾配は 1/510-1/290 を示し, 河床材料は微細砂〜粗砂である.

一方，秃尾河，佳芦河は，いずれも黄土丘陵を通 過し, 秃尾河の河床勾配は 1/430 1/220, 佳芦河は 1/220〜1/105 である.

これら 3 つの河川流域の年平均降雨量は $500 \mathrm{~mm}$ 弱を 示し, 大部分は 7 月と 8 月の時期に集中している. 出水 時には急激に水位が上昇し，ピーク時で最大 30 50\%も の土砂を高濃度に含有した洪水が流下している.

\section{3. 現地観測資料の解析}

窟野河，秃尾河，佳芦河の水理・水文観測点において 1979 年, 1980 年および 1981 年に実測された雨量, 流量, 流砂量の資料5)を解析し, 流域の流出特性, 洪水流によ る土砂輸送の特性，流れの抵抗則について調べる.

\section{(1) 流出係数}

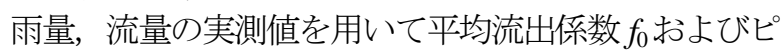
一ク流出係数 $f_{p}$ をそれぞれ次式によって求める.

$$
\begin{aligned}
& \int Q d t=10^{3} f_{0} R A \\
& Q_{p}=\frac{1}{3.6} f_{p} \bar{r} A
\end{aligned}
$$

表-1 流域特性

\begin{tabular}{|c|c|c|}
\hline & 流域面積 $\left(\mathrm{km}^{2}\right)$ & 流路延長 $(\mathrm{km})$ \\
\hline 窟野河 & 8,706 & 241.8 \\
\hline 秃尾河 & 3,253 & 130 \\
\hline 佳芦河 & 1,121 & 75 \\
\hline
\end{tabular}

ここに, $\int Q d t$ : 総流量 $\left(\mathrm{m}^{3}\right), Q_{p}$ : ピーク流量 $\left(\mathrm{m}^{3} / \mathrm{s}\right), A$ : 流域面積 $\left(\mathrm{km}^{2}\right), R$ : 総降雨量 $(\mathrm{mm}), \bar{r}$ : ピーク到達時間 内の平均降雨強度 $(\mathrm{mm} / \mathrm{h})$ である.

得られた流出係数 $f_{0}$ は $0.05 \sim 0.62$ (平均 0.215 ) を示し, 日本の河川に比べ小さな值となっている. これは，調査 対象河川流域の大部分が乾燥地域で裸地であるため，浸 透量や蒸発散量が多いことによるものと考えられる。一 方, ピーク流出係数は $f_{p}=0.05 \sim 1.57$ (平均 0.55 ) となり, 1 より大きな值をとる場合もある. バラツキが大きいが, 平均的に見ると, ピーク流出係数 $f_{p}$ は平均流出係数 $f_{0}$ よ り 2 倍以上大きくなっており, これはピーク時に土砂を 高濃度に含有するためであると考えられる.

\section{（2）流砂の粒度特性}

黄河流域では，流下寸る土砂の粒径が，支川ごとに大 きく異なることが知られている ${ }^{4)}$. また洪水規模や流砂 濃度によっても变化する，そこで，窟野河について洪水 流中の流砂の濃度 $C_{T}$ と $50 \%$ 粒径 $d_{50}$ との関係を調べた。 窟野河では，流砂濃度 $C_{T}=0.01 \sim 0.05$ を境にして，それ 以下では平均的に $d_{50}=0.02 \mathrm{~mm}$ 程度となるが，それ以上 になると濃度とともに流砂の粒径が増加する. 最大濃度 $C_{T}=0.5$ 付近では $d_{50}=0.5 \mathrm{~mm}$ 程度となる.

\section{（3）流砂濃度の特性}

図-3, 4 は窟野河，佳芦河について流砂濃度と流量と の関係を調べた結果である。 まず，窟野河（図-3）にお いて,データのバラツキが大きいが, 大略の傾向として, 濃度が約 0.1 以下の領域では, 濃度 $C_{T}$ は流量 $Q$ に従っ て増加し, 比例関係となる. 一方, 濃度が約 0.1 以上の 領域になると, 濃度の増加は頭打ちの傾向を示し $0.1\left\langle C_{T}<0.5\right.$ の間でほぼ一定な傾向を示す. 流砂濃度は最 密充填濃度 (約 0.6) を越えることはできないので, $0.1\left\langle C_{T}\langle 0.5\right.$ の間でほぼ一定な值を示すのは当然のこと である．中国の文献 ${ }^{4) ， 6)}$ において良く指摘されているこ ととして, 流量の増加とともに流砂量 $Q_{s}$ が増加し, 最終 的には流砂量 $Q_{s}$ が流量 $Q$ に比例する関係に収斂してい くことが指摘されている. 従って, 上述のことは, 従来 の流砂量と流量との関係を言い換えた結果となっている.

さて, 実河川における流砂観測によると, ウォッシュ ロードの濃度と流量とは比例関係にあることが知られて いる ${ }^{7)}$. 窟野河は，ウォッシュロードの輸送特性と同様 な関係を示している.

次ぎに，佳芦河（図-4）では，流砂濃度が約 0.1 以下 の領域では $C_{T} \propto Q^{2.5}$ の関係となり, 流砂濃度が約 0.1 以 上になるとほぼ一定な值となる。 


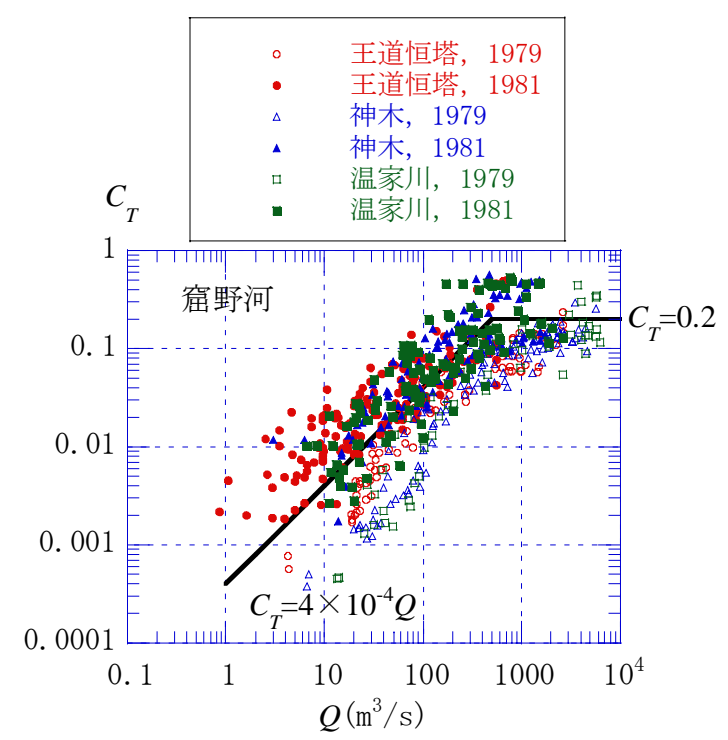

図-3＼cjkstart窟野河における流砂濃度と流量との関係

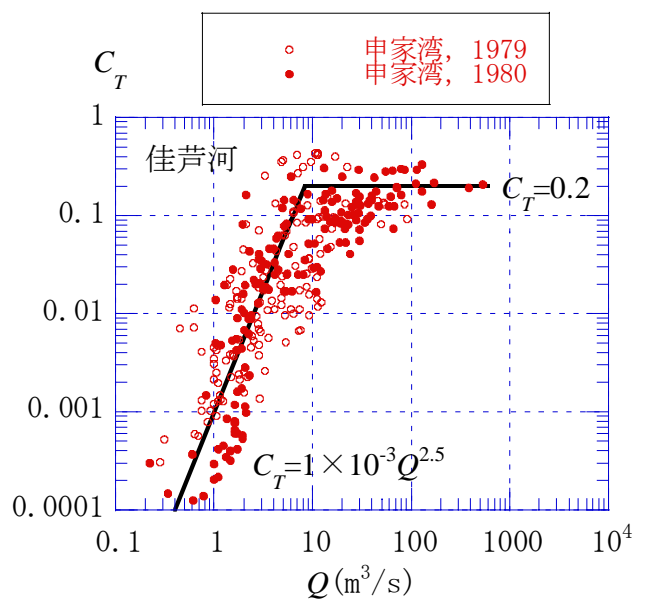

\section{図-4＼cjkstart佳芦河における流砂濃度と流量との関係}

そこで，各支川における流量と流砂濃度の観測值から それらの関係式を求めると以下のようになる.

a）窟野河

b) 秃尾河

$$
\begin{aligned}
& Q \leq 500\left(\mathrm{~m}^{3} / \mathrm{s}\right) \text { の場合 } C_{T}=4.0 \times 10^{-4} Q \\
& Q \geq 500\left(\mathrm{~m}^{3} / \mathrm{s}\right) \text { の場合 } C_{T}=0.2
\end{aligned}
$$

$$
\begin{array}{ll}
Q \leq 70.7\left(\mathrm{~m}^{3} / \mathrm{s}\right) \text { の場合 } & C_{T}=4.0 \times 10^{-5} Q^{2} \\
Q \geq 70.7\left(\mathrm{~m}^{3} / \mathrm{s}\right) \text { の場合 } \quad C_{T}=0.2
\end{array}
$$

\section{c）佳芦河}

$$
\begin{aligned}
& Q \leq 8.32\left(\mathrm{~m}^{3} / \mathrm{s}\right) \text { の場合 } C_{T}=1.0 \times 10^{-3} Q^{2.5} \\
& Q \geq 8.32\left(\mathrm{~m}^{3} / \mathrm{s}\right) \text { の場合 } C_{T}=0.2
\end{aligned}
$$

流砂濃度 $C_{T}$ は, 窟野河では流量 $Q$ の 1 乗に比例し, 秃尾河, 佳芦河では $Q$ の $2 \sim 2.5$ 乗に比例している. 従 って, 窟野河の流砂形態と秃尾河, 佳芦河の流砂形態と は異なるが，秃尾河の流砂形態と佳芦河のそれとは類似 していることが考えられる.

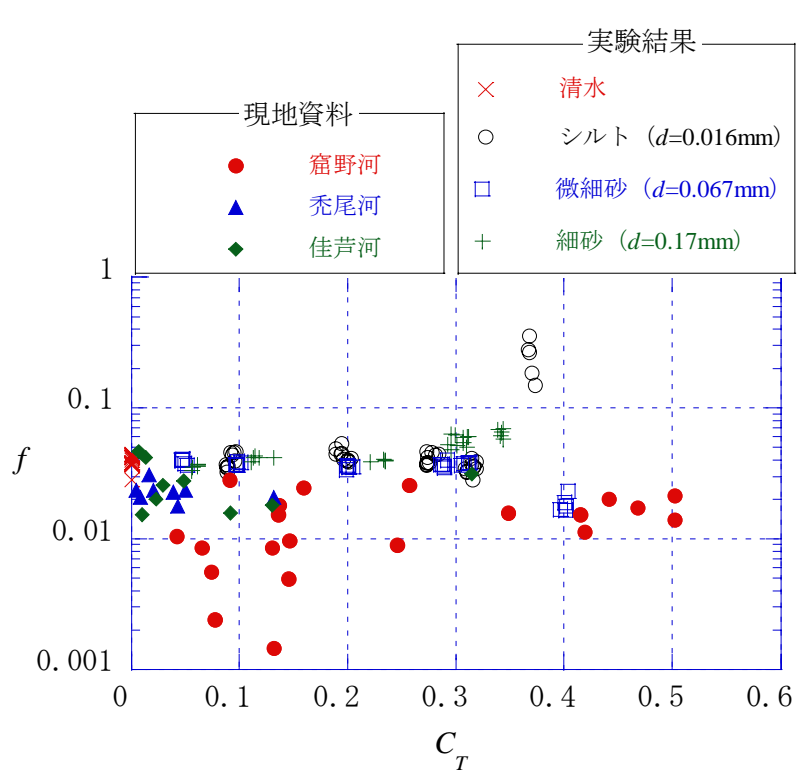

図-5 摩擦損失係数と土砂輸送濃度の関係

\section{（4）洪水流の抵抗}

図-5 は, 洪水ピーク時における流れの摩擦損失係数 $f$ と流砂濃度 $C_{T}$ との関係を調べたものである. 図中には, 循環水路において実施した高濃度流れの実験結果 3)も示 している．窟野河では $f=0.0015 \sim 0.027$ ，秃尾河では $f=0.018 \sim 0.031$, 佳芦河では $f=0.015 \sim 0.047$ である.

一方，水路実験においては，シルト・水の混相流の場 合，高濃度においてビンガム流体の挙動を示し 3)，その 結果, $f$ が 0.1 以上の值となっている. これを除くと, 水 路実験では多くはf $=0.02 〜 0.07$ である.

以上のことから，現地観測の $f$ は水路実験に比べて小 さな值を示している. 特に, 窟野河ではかなり小さいこ とが分かる.これらについては4 章(2)節で考察される. また, 本研究の範囲内においては, 大部分は, ビンガム 流体とは異なる挙動をしていると考えられる.

\section{4. 高濃度洪水の抵抗と流砂量則}

正確な土砂流出予測には，河道における高濃度洪水の 普遍的な抵抗と流砂量則の解明が必要である．高濃度洪 水は高濃度の含有土砂のため, 流砂濃度の増加とともに 抵抗則などの流孔特性を変化させる。 ここでは, 既往の モデルとして，ニュートン流体における見かけ粘性係数 が流砂濃度により変化し, その結果として抵抗則が変わ るものとするモデル（以後, ニュートン流体モデルと呼 ぶ）と，ダイラタント流体型の土石流モデルを基礎とし て展開された泥流型土石流モデル 8) 11) (以後, 非ニュー トン流体モデルとも呼ぶ）とを取り上げ，それらの黄河 支流一の適合性を検討することとする.

ここに，ニュートン流体モデルは抵抗則のみを議論す るのに対して, 非ニュートン流体モデル（泥流型土石流 モデル)は抵抗と流砂量則の同時解を考察の対象とする. 

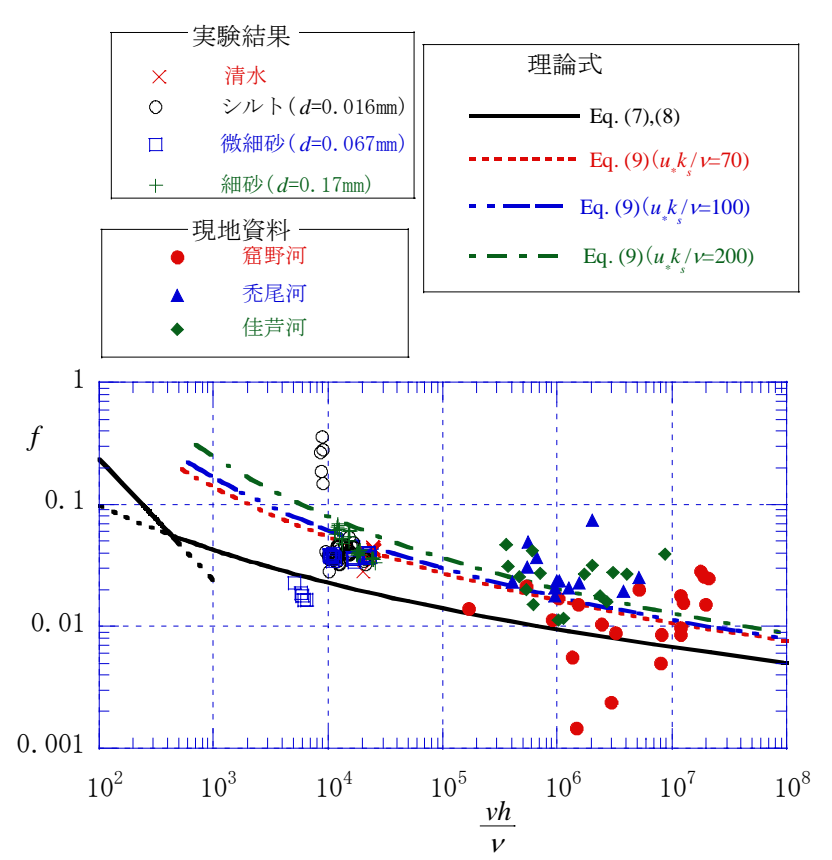

図-6 摩擦損失係数とレイノルズ数の関係 (ニュートン流体モデル)

（1）流動モデル

a） ニュートン流体モデル

このモデルは, 流砂濃度による抵抗則の変化を見かけ 粘性係数の変化として説明するモデルである. その評価 式としては高濃度の領域に適用可能な森・乙武の相対粘 度式 ${ }^{12)}$ 用いる。

$$
\eta_{r}=1+\frac{3}{\left(1 / C_{T}-1 / 0.52\right)}
$$

ここに, $\eta_{r}$ : 相対粘度, $C_{T}$ : 流砂濃度である. 従って $\mu_{0}$ を清水の粘性係数とすると, 流れの見かけ粘性係数 $\mu_{a}$ は $\mu_{a}=\mu o \eta_{r}$ として得られる.

さてニュートン流体の抵抗則は，広長方形開水路にお いては，vh/vミ500（層流）の場合

$$
\frac{v}{u_{*}}=\sqrt{\frac{8}{f}}=\sqrt{\frac{v h}{3 v}}
$$

ここに $v$ : 平均流速, $u_{*}$ : 摩擦速度, $v$ : 動粘性係数であ る. $\rho_{t}$ を流れの密度として $v=\mu_{a} / \rho_{t}$ である. さらに $v h / v \gtrsim 500$ (乱流) の場合, 底面粗度の大小により, 滑面 においては

$$
\frac{v}{u_{*}}=\sqrt{\frac{8}{f}}=5.5-\frac{1}{\kappa}+\frac{2.3}{\kappa} \log _{10}\left(\frac{v h}{v} \sqrt{\frac{f}{8}}\right)
$$

となり, 完全粗面においては
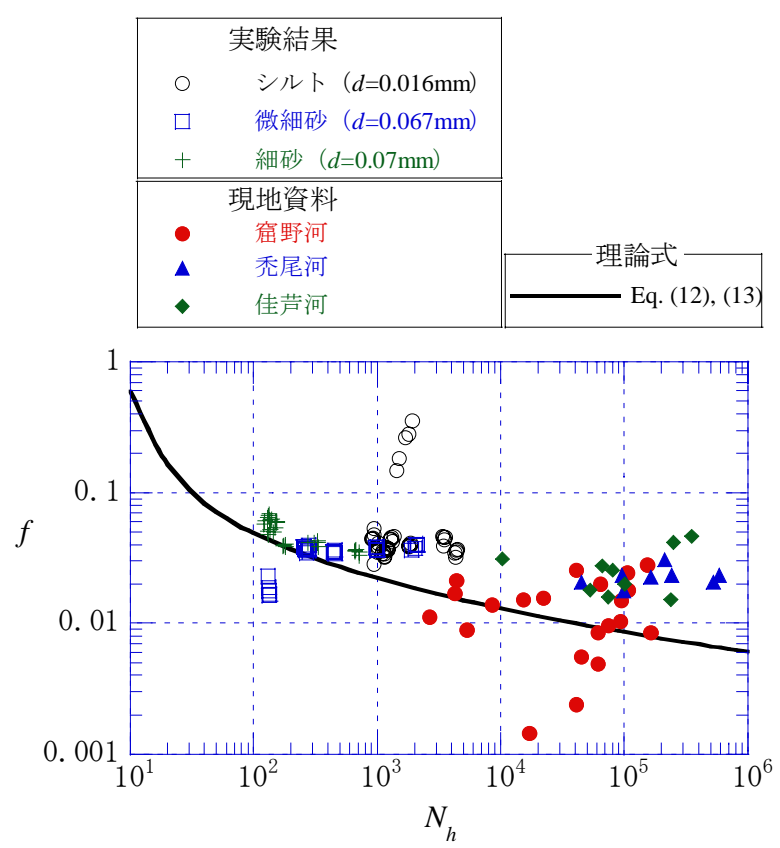

図-7 摩擦損失係数と無次元水深の関係 （非ニュートン流体モデル）

$$
\frac{v}{u_{*}}=\sqrt{\frac{8}{f}}=8.5-\frac{1}{\kappa}+\frac{2.3}{\kappa} \log _{10}\left(\frac{v h}{v} \sqrt{\frac{f}{8}} / \frac{u_{*} k_{s}}{v}\right)
$$

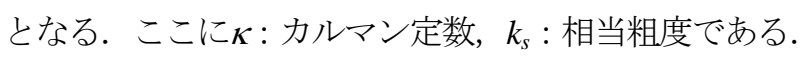

b) 非ニュートン流体モデル（泥流型土石流モデル）

泥流型土石流モデルは乱流化した土石流に対して提案 されたモデルである．例えば，橋本ら $\left.{ }^{8}, 9\right)$ のデルは以 下のようである。

彼らは, 土石流の運動方程式において慣性項と抵抗項 との比をとることにより, 流れを表す無次元量 $N_{L}$ として 次式を導入した.

$$
N_{L}=\frac{L}{d} \sqrt{\frac{\rho_{t}}{\sigma F\left(C_{T}\right)}}
$$

ここに $L$ : 代表長さスケール,$d$ : 流砂の代表粒径, $\rho_{t}$ : 流れの密度, $\sigma$ : 粒子密度, $F\left(C_{T}\right): C_{T}$ の関数である. $C_{*}$ を最密充填濃度として

$$
F\left(C_{T}\right)=\frac{\left(C_{T} / C_{*}\right)^{2}}{1-C_{T} / C_{*}}
$$

である. さらに彼らは，Lとして底面からの高さ $z$ をと ることで，底面近傍には粒子間応力が卓越する粒子間力 層が，その上にはレイノルズ応力の卓越した慣性力層が それぞれ存在するものと考え，その考察に基づき 2 層構 造モデルを提案した.

その結果，抵抗則は， $N_{h} \leq 15$ の場合

$$
\frac{v}{u_{*}}=\sqrt{\frac{8}{f}}=\frac{1}{2} \frac{\xi}{\sqrt{K_{z x}}} N_{h}
$$

$N_{h}>15$ の場合 

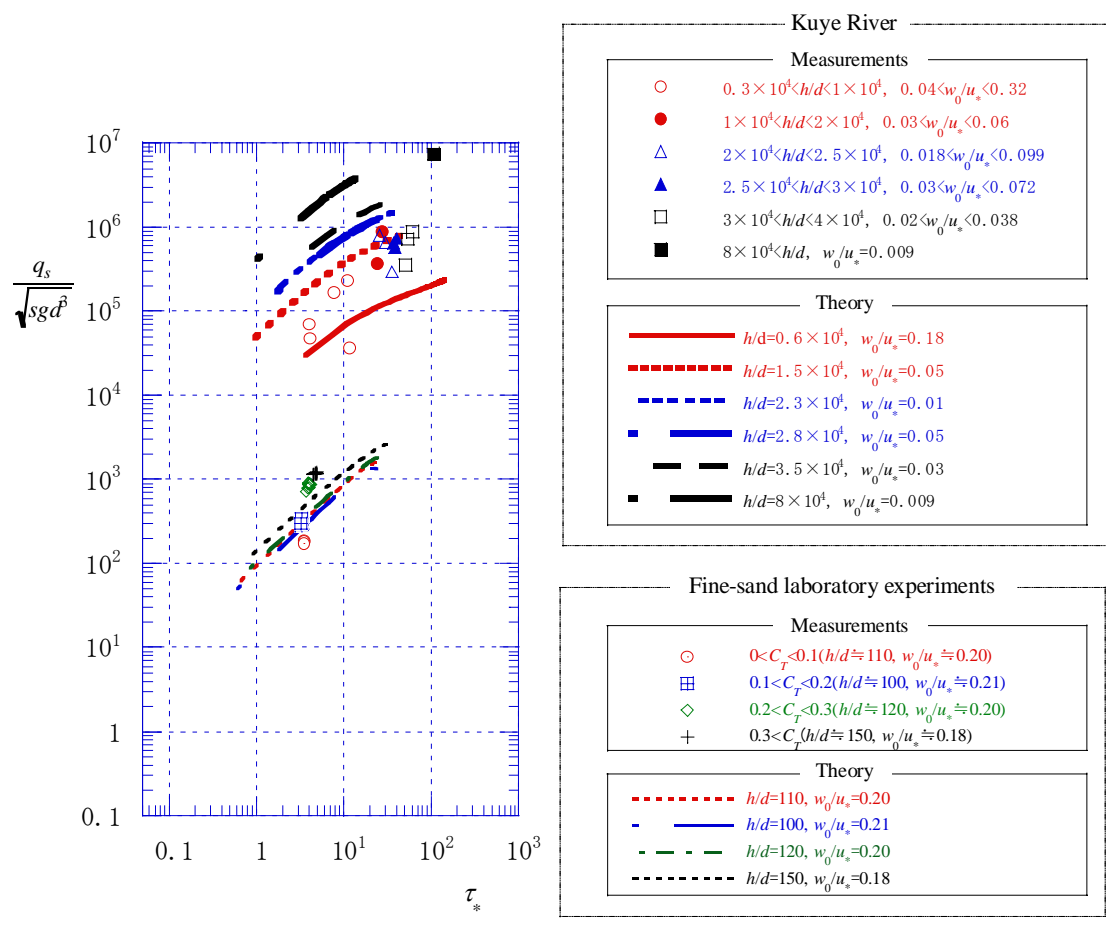

図-8 無次元流砂量と無次元掃流力との関係（非ニュートン流体モデル）
おいて細砂，微細砂，シルトを用い て実施された実験結果 3)も合わせて 示している. また, 図中の曲線は二 ユートン流体モデルの理論式(7),

（8），(9）の計算結果である. 水路実 験の $R e$ 数は, $10^{4}$ 前後であるのに対 し，現地観測のそれは $10^{5} \sim 10^{7}$ の範 囲である. 現地観測および水路実験 結果は,データのばらつきが大きく, 一部のデータを除いて考えると，概 ね, 完全粗面式(9) と一致している. ここに $u_{*} k_{s} / v=70$ 程度である.

図-7 は, 摩擦損失係数 $f$ を無次元 水深 $N_{h}$ に対して示した結果である. $N_{h}$ 数の值は, 現地観測では $10^{3} \sim 10^{5}$ の範囲となるのに対して，水路実験 では $10^{2} \sim 10^{3}$ の範囲である. 細砂の 実験結果および窟野河の観測データ は非ニュートン流体モデル（泥流型 土石流モデル）の理論式(12), (13) とほぼ一致しているが，他の水路実

$$
\frac{v}{u_{*}}=\sqrt{\frac{8}{f}}=\frac{15}{2} \frac{\xi}{\sqrt{K_{z x}}} \frac{15}{N_{h}}+\left(\frac{u_{\delta}}{u_{*}}-\frac{1}{\kappa}\right)\left(1-\frac{15}{N_{h}}\right)-\frac{1}{\kappa} \ln \left(\frac{15}{N_{h}}\right)
$$

となる.ここに， $N_{h}$ は流れを規定する無次元量であり， 次式により定義される.

$$
N_{h}=\frac{h}{d} \sqrt{\frac{\rho_{t}}{\sigma F\left(C_{T}\right)}}
$$

また

$$
\begin{gathered}
K_{z x}=(\pi / 6)(0.0762+0.102 \mu) \beta^{2} k_{M} \\
\frac{u_{\delta}}{u_{*}}=\frac{15 \xi}{\sqrt{K_{z x}}}
\end{gathered}
$$

である.ここに， $\xi=0.4, \mu=0.1, \beta=1.15, k_{M}=5$ であ る.さらに橋本らは，2 層構造モデルから広範な流砂形 態に適用可能な流砂量式を次のように求めた 10), 11).

$$
\frac{q_{s}}{\sqrt{s g d^{3}}}=\frac{\bar{u}_{\delta}}{u_{*}} \tau_{*}^{3 / 2}\left(1-\frac{\tau_{*_{c}}}{\tau_{*}}\right) \frac{1}{\left(\alpha-I_{f}\right) \cos \theta} G\left(I_{f}, \frac{h}{d}, \frac{w_{0}}{u_{*}}\right)
$$

ここに, $q_{s}$ : 単位幅流砂量, $s$ : 粒子比重, $d$ : 粒径, $g$ : 重力加速度, $\tau_{*}$ : 無次元掃流力, $I_{f}$ : エネルギー勾配, $w_{0}$ : 粒子の沈降速度, $u_{*}$ : 摩擦速度, $G\left(I_{f}, h / d, w_{0} u_{*}\right): I_{f}, h / d, w_{0} u_{*}$ の関数である. また， $\alpha=0.875, \bar{u}_{\delta} / u_{*}=4.7$ である.

\section{（2）流動モデルと現地観測・水路実験との比較}

図-6 は, 各支川の洪水流について摩擦損失係数 $f$ と $R$ 数=vh/vとの関係を示したものである.ここに循環水路に
験結果および秃尾河, 佳芦河のデータはその理論式とは 異なっている.

図-5において述べた, 現地観測と水路実験結果との顕 著な差異は, $R e$ 数や $N_{h}$ 数の值の差異に起因しているこ とが分かる。

図-8は, 窟野河の流砂量および細砂を用いた水路実験 結果について，無次元流砂量と無次元掃流力との関係を 示したものである.ここに図中の曲線は式（17）の計算 結果である. 窟野河の水理量は相対水深 $h / d=10^{4}$, 粒子沈 降速度・摩擦速度比 $w_{0} / u_{*}=10^{-2}$ のオーダーの範囲である のに対して, 細砂実験のそれは相対水深 $h / d=10$, 粒子沈 降速度・摩擦速度比 $w_{0} / u_{*}=10^{-1}$ のオーダーの範囲である. 水理条件が大きく異なる領域の流砂量であるが，これら は，同一の流砂量式によって示されることがわかる.

一方，秃尾河と佳芦河の流砂量および微細砂，シルト を用いた水路実験結果については, 眓は省略しているが, 式(17)は適合しなかった。これは，窟野河が砂河川であ るのに対して, 秃尾河と佳芦河の流砂はより細粒のシル ト〜微細砂であるため土砂輸送特性が異なることによる ものと考えられる.

以上により，窟野河における洪水流の観測および細砂 を用いた水路実験結果については非ニュートン流体モデ ル（泥流型土石流モデル）が流れの抵抗と流砂量を同時 に説明し, 秃尾河, 佳芦河における洪水流およびシルト・ 微細砂の水路実験結果については，ニュートン流体モデ ルが流れの抵抗を表すことができるものと考えられる.

\section{5. 流出解析に基づく流砂量ハイドログラフの評価}

本章では，まず，窟野河において，流域内の観測雨量 を用いて貯留関数法による流出解析を行い，実測ハイド 
ログラフと比較し, パラメータ $k_{1}, k_{2}$ の 同定を行う. 次に流出解析より得られた 流量から流砂量式を用いて流砂量ハイド ログラフを求め, 実測結果と比較する.

図-9 は, 貯留関数法 13)を用いて流出解 析を行った結果の 1 例である.ここに, 図中の $f_{0}$ は流出係数であり, 3 章 (1) 節 において決定されたものである.

得られた流量ハイドログラフから，流 れを等流と仮定し，河川断面を長方形と して次式より水深を求める.

$$
Q=B h \sqrt{\frac{8}{f}} \sqrt{g h I}
$$

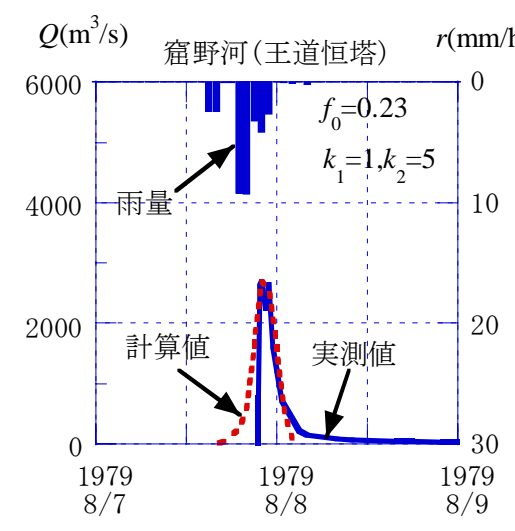

図-9＼cjkstart流量ハイドログラフの観測 值と計算値との比較

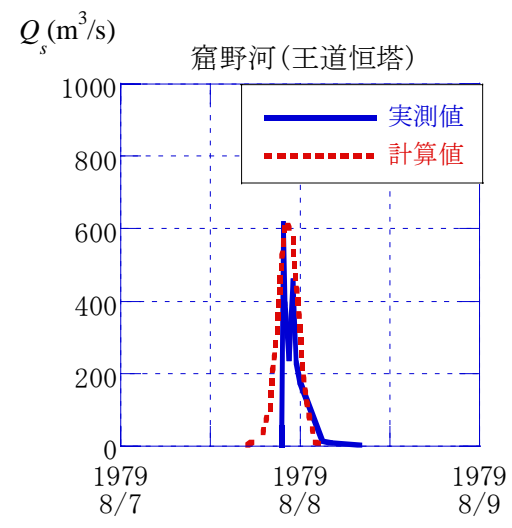

図-10＼cjkstart流砂量ハイドログラフの 観測值と計算値との比較
ここに, $Q$ : 流量, $f$ : 摩擦損失係数, $h:$ 水深, $I$ : 河床 勾配である. 摩擦損失係数 $f$ については窟野河では式 （12），（13）を用いる. 上式から求めた水深を式(17)に代 入すると流砂量を得る.

図-10 は，このようにして求めた流砂量八イドログラ フの計算值と観測值との比較である. 計算值は観測值と 概䍩一致している. 従って, 流出解析により水文観測点 における流量ハイドログラフが得られれば，その結果と 流砂量式を用いて流砂量ハイドログラフを評価すること ができる.

\section{6. おわりに}

本研究は, 黄河中流支川の窟野河, 秃尾河, 佳芦 河を対象とし，それらで発生する高濃度洪水につい て, 現地観測資料の解析を通じて, 実験室とは異なる大 規模流量における流れの抵抗則や土砂輸送の特性を調心゙ るとともに，その成果をもとに，流砂量八イドログラフ の評価法を明らかにした。

まず, 窟野河の洪水流および細砂を用いた水路実験結 果については, 非ニュートン流体モデル（泥流型土石流 モデル）が流れの抵抗と流砂量を同時に説明することが できた. 窟野河について流出解析より得られた流量八イ ドログラフから, 普遍的な流砂量式（17）を用い, 流砂 量ハイドログラフを求めることができた．さらに，観測 点において流量ハイドログラフが得られれば，それを境 界条件として河床変動解析を行うことが可能となり, 任 意地点における流量, 流砂量ハイドログラフの予測がで きるようになる.

一方，秃尾河，佳芦河の洪水流およびシルト・微細砂 を用いた水路実験結果については, ニュートン流体モデ ルが流れの抵抗を説明することができた．流砂量につい ては，実測結果に基づく経験式（4），(5) を用いること で，当該地点における流砂量評価は可能となった. しか し, 任意地点における流量, 流砂量評価は困難であり, 普遍的流砂量式の開発が課題として残った.
謝辞 : 本研究は, 一部, 科学技術振興事業団・戦略的基 礎研究推進事業「黄河流域の水利用・管理の高持続性化」

(代表 楠田哲也 九州大学特任教授)の補助の下にお こなわれたものである. 現地調査や資料入手においては 中国の清華大学の方紅衛, 王兆印教授より便宜を計って いただいた．ここに記して謝意を表します.

\section{参考文献}

1）芦田和男・山野邦明・神田昌幸 : 高濃度流孔に関寸る研究 (1), 京都大学防災研究所年報, 第 28 号, pp. 367 377, 1982.

2）芦田和男・山野邦明・神田昌幸: 高濃度流机に関寸る研究 (2), 京都大学防災研究所年報, 第29号, pp. 361 375, 1983.

3）橋本晴行 - 高岡広樹 - 池松伸也 - 全炳徳 -上野賢仁 : 黄河 中流域における河道堆積土砂調查と高濃度流れの水路実 験, 水工学論文集, 第 48 巻, pp. 943 948, 2004.

4) Zhaohui Wan and Zhaoyin Wang: Hyperconcentrated Flow, IAHR/AIRH MONOGRAPH, 1994.

5) Yellow River Conservancy Commission: Data of Water and Sediment of the Yellow River, 1980 and 1982 (in Chinese).

6) Cao Ruxuan, Fan Erlan and Qin Yi : Sediment transport models for small gullies in loess hill and gully regions, Proceedings of the International Symposium on the Hydraulics and Hydrology of Arid Lands, ASCE, 694-699,1990.

7) 芦田和男・高橋保・道上正規: 河川の土砂災害と対策, 森 北出版 (株), 1983.

8) 橋本晴行・平野宗夫 : 泥流の抵抗則に関する研究, 水工学 論文集，第39巻，pp. 495 500， 1995.

9) Haruyuki Hashimoto and Muneo Hirano : A FLOW MODEL OF HYPERCONCENTRATED SAND-WATER MIXTURES,

Debris-Flow Hazards Mitigation : Mechanics, Prediction, and Assessment, Proceedings of First International Conference, ASCE, August 7-9, pp. 464 473, 1997.

10）平野宗夫・橋本晴行・多川博章: 急勾配水路における浮流 砂を伴う流砂量, 水工学論文集, 第 42 巻, pp. 1069 1074, 1998.

11）橋本晴行 - 朴埼骤・池松伸也・田崎信忠: 急勾配移動床水 路における種々の流砂形態に対寸る統合的流砂量式, 水工 学論文集, 第 47 巻, pp. 571 576, 2003.

12）森芳郎・ 乙竹直: 懸濁液の粘度について, 化学工学, 20 巻, 9 号, 488-494, 1956.

13）土木学会: 水理公式集（平成 11 年版), 1999.

(2006. 9. 30受付) 